\title{
Trends in mechanical aortic valve replacement surgery in a large, multi-surgeon, single hospital practice
}

\author{
Mehmet Kalender ${ }^{1}$, Ali Fedakar², Taylan Adademir ${ }^{2}$, Salih Salihi ${ }^{3}, K^{2}$ imil Boyacıoğlu ${ }^{4}$ Babürhan Özbek², \\ Mehmet Taşar ${ }^{5}$, Mehmet Balkanay ${ }^{2}$ \\ ${ }^{1}$ Department of Cardiovascular Surgery, Konya Education and Research Hospital, Konya, Turkey \\ ${ }^{2}$ Department of Cardiovascular Surgery, Kartal Kosuyolu Yuksek Ihtisas Education and Research Hospital, \\ Istanbul, Turkey \\ ${ }^{3}$ Department of Cardiovascular Surgery, Nigde Public Hospital, Nigde, Turkey \\ ${ }^{4}$ Department of Cardiovascular Surgery, Bagcilar Education and Research Hospital, Istanbul, Turkey \\ ${ }^{5}$ Department of Cardiovascular Surgery, Ankara University Hospital, Ankara, Turkey \\ Kardiochirurgia i Torakochirurgia Polska 2014; 11 (4): 367-372
}

\begin{abstract}
Introduction: In recent decades, new high-performance prostheses have been invented for use with small aortic annuli, and they have helped avoid patient prosthesis mismatch (PPM) without the need for aortic annular enlargement. The purpose of this study is to examine the trends in mechanical aortic valve replacement surgery in a large, multi-surgeon, single hospital practice.

Material and methods: Between January 1999 and January 2008, 1337 consecutive patients underwent aortic valve replacement (AVR) with or without concomitant aortic annulus enlargement. Patients with aortic dissections and patients undergoing Bentall and Ross procedures were excluded from the analysis. Patients were grouped according to the used aortic valve size. The data were collected and analyzed retrospectively.

Results: The mean age of the subjects was $54.37 \pm 17.35$ (range: 10-84), and 881 of them were men (65.8\%). The number of aortic root enlargement procedures decreased over the years $(p<0.05)$; particularly, the decline of the Nicks procedures was statistically significant $(p<0.05)$. In 2008, the most frequently used valve size was 23 , which stands in contrast with the smaller size preferred in $1999(p<0.05)$. The primary pathophysiology leading to aortic valve replacement, i.e. aortic stenosis, did not change over the years $(p>0.05)$. Although the use of combined surgery increased in time, there was no statistical relationship with any increase in mortality rates $(p>0.05)$.

Conclusions: This study showed that avoiding the procedure of aortic root enlargement and implanting high-performance prostheses with larger valves is safe.
\end{abstract}

Key words: aortic valve, aortic root, mechanical valve.

\section{Streszczenie}

Wstęp: W ostatnich dekadach wprowadzono do użytku nowe, wysokiej jakości zastawki stosowane w małych pierścieniach aortalnych, które pozwalają na uniknięcie niedopasowania zastawki (patient prosthesis mismatch - PPM). Celem pracy było przeanalizowanie tendencji występujących w operacjach wymiany mechanicznych zastawek aortalnych w pojedynczym, dużym szpitalu zatrudniającym wielu chirurgów.

Materiał i metody: Między styczniem 1999 r. a styczniem 2008 r. 1337 kolejnych pacjentów przeszło operacje wymiany zastawki aortalnej (aortic valve replacement - AVR) z jednoczesnym powiększeniem pierścienia zastawki lub bez jego powiększenia. Pacjenci z rozwarstwieniami aorty oraz poddani operacjom Bentalla i Rossa zostali wyłączeni z badania. Badanych podzielono na grupy na podstawie użytego rozmiaru zastawki aortalnej. Dane zebrano i przeanalizowano retrospektywnie.

Wyniki: Średni wiek pacjentów wyniósł $54,37 \pm 17,35$ roku (zakres: 10-84 lata); 881 z nich stanowili mężczyźni (65,8\%). W badanym okresie liczba wykonywanych operacji powiększenia korzenia aorty zmniejszała się $(p<0,05)$; istotne statystycznie było przede wszystkim zmniejszenie liczby wykonywanych operacji Nicksa $(p<0,05)$. W 2008 r. preferowanym rozmiarem zastawki był rozmiar 23, w odróżnieniu od mniejszych rozmiarów preferowanych w 1999 r. $(p<0,05)$. Główna patofizjologiczna przyczyna wymiany zastawki aortalnej, tzn. zwężenie zastawki aortalnej, nie uległa zmianie $w$ badanym okresie ( $p>0,05$ ). Pomimo zwiększającego się $\mathrm{w}$ czasie przeprowadzania operacji łączonych, nie zaobserwowano statystycznego związku tego typu operacji ze wzrostem śmiertelności $(p>0,05)$. Wnioski: Niniejsza praca wykazała, że unikanie operacji powiększenia korzenia aorty i wszczepianie protez wysokiej jakości o większym rozmiarze jest bezpieczne.

Stowa kluczowe: zastawka aortalna, korzeń aorty, zastawka mechaniczna.

Address for correspondence: Mehmet Kalender, MD, Konya Eğitim ve Araştırma Hastanesi Kalp Damar Cerrahisi Kliniği, Haci Saban Mah. Meram Yeni yol caddesi no:92 Meram, Konya 42040, Turkey, phone: +905054424786, e-mail: ka97084@yahoo.com 


\section{Introduction}

The main purpose of aortic valve replacement (AVR) is to reduce the pressure or volume load on the left ventricle and thus avoid the progression of left ventricular remodeling. During the last 5 decades, valve prosthetics have evolved, and their usage expanded greatly. However, small aortic root size in comparison to body mass index (BMI) continues to pose a challenge for cardiac surgeons. In recent decades, new high-performance prostheses have been invented for use with small aortic annuli, and these have contributed to the avoidance of patient prosthesis mismatch (PPM) without the need for aortic annular enlargement.

In this study, we report the trends of aortic valvular replacement and root enlargement operations performed in our clinic between 1999 and 2008.

\section{Material and methods}

Between 1999 and 2009, we performed open heart surgery on 16764 patients. Of these operations, 4687 involved valve surgery. Aortic valve operations were less common than mitral valve repair. During this period, we conducted 1397 aortic valve operations, including 60 aortic valve reconstructions.

The data of 1337 consecutive patients who underwent AVR with or without concomitant posterior aortic annulus enlargement between January 1999 and January 2009 were included in the study. Patients with aortic dissections and patients who underwent Bentall and Ross procedures were excluded from the analysis. Patients were grouped according to the employed aortic valve size. The data were collected and analyzed retrospectively.

Tab. I. Study parameters

\begin{tabular}{|c|c|c|c|}
\hline \multicolumn{2}{|l|}{ Parameter } & \multirow[t]{2}{*}{$n$} & \multirow[t]{2}{*}{$\%$} \\
\hline Age (year) & $54.37 \pm 17.35($ range $10-84)$ & & \\
\hline $\operatorname{Sex}(f)$ & & 456 & 34.1 \\
\hline Aortic stenosis & & 703 & 52.5 \\
\hline Aortic regurgitation & & 435 & 32.5 \\
\hline Regurgitation + stenosis & & 199 & 14.8 \\
\hline \multirow[t]{4}{*}{ Additional disease } & Mitral regurgitation & 225 & 34.8 \\
\hline & Mitral stenosis & 90 & 13.9 \\
\hline & Ascending aortic aneurysm & 170 & 26.3 \\
\hline & Other & 160 & 24.8 \\
\hline \multirow[t]{6}{*}{ Aortic valve size } & 19 & 106 & 7.9 \\
\hline & 21 & 526 & 39.3 \\
\hline & 23 & 468 & 35.0 \\
\hline & 25 & 223 & 16.7 \\
\hline & 27 & 12 & 0.9 \\
\hline & 29 & 2 & 0.1 \\
\hline \multirow[t]{2}{*}{ Aortic root enlargement } & Nicks & 25 & 1.9 \\
\hline & Manouguian & 6 & 0.4 \\
\hline \multirow[t]{2}{*}{ Additional procedure } & Mitral valve replacement & 312 & 23.3 \\
\hline & Other & 333 & 24.9 \\
\hline \multirow[t]{5}{*}{ Mitral valve size } & 25 & 17 & 5.6 \\
\hline & 27 & 73 & 23.3 \\
\hline & 29 & 121 & 38.9 \\
\hline & 31 & 80 & 25.6 \\
\hline & 33 & 21 & 6.7 \\
\hline Redo & & 37 & 2.8 \\
\hline Hospital mortality & & 33 & 2.5 \\
\hline
\end{tabular}


All patients were operated on using median sternotomy and were placed on cardiopulmonary bypass with high aortic and dual-stage right atrial cannulation. A membrane oxygenator and arterial filter were routinely used. Antegrade and retrograde warm and cold blood cardioplegia was employed. Prostheses were implanted into the intraannular position with interrupted pledgeted sutures. Patients who required annular enlargement underwent either the Nicks [1] or the Manouguian procedure [2].

The data were analyzed using SPSS (Statistical Package for Social Sciences) version 15, 2006 Statistical Software (USA). Continuous variables were summarized as mean and standard deviation, while categorical variables were described as the number of subjects and percentage. In the study, we classified numeric variables, and we used a $\chi^{2}$ test for univariate analysis. The Mann-Whitney test and 1-way ANOVA (Kruskal-Wallis and Dunn's multiple comparison tests) were used as appropriate. $P$ values $<0.05$ were considered statistically significant, and the confidence interval was $95 \%$.

\section{Results}

The mean age of the study population was $54.37 \pm 17.35$ (range: $10-84)$. Men constituted $65.8 \%$ of the study group ( $n=881)$. Seven hundred and three $(n=703)(52.5 \%)$ patients were diagnosed with isolated aortic stenosis, 199 (14.8\%) with both aortic stenosis and regurgitation. The Nicks procedure was performed in 25 patients (1.9\%). Study population properties are summarized in Table I and II.

No relationship was observed between age and preferred valve size $(p>0.05)$. However, sex did affect the valve size: female patients were implanted mostly with 19 or 21 sized valves, while male patients were more often implanted with size 23 or 25 ( $p<0.01$ ).

We observed an absolute increase in the number of aortic valve replacement procedures during the studied period (75 cases in 1999 and 194 cases in 2008). The number of aortic root enlargement procedures decreased over the years $(p=0.0002)$; particularly, the decline of the Nicks procedure was statistically significant (5 cases in 1999 and 2 cases in 2008) $(p<0.05)$. It was noteworthy that despite the decrease in the number of aortic root enlargement operations, the preferred valve size increased. In 2008, the most frequently used valve size was 23 , whereas size 21 was preferred in 1999 ( $p<0.05)$. The primary pathophysiology leading to aortic valve replacement, aortic stenosis, did not change over the years $(p>0.05)$. Although the use of combined surgery increased over the years, there was no statistically significant increase in mortality rates $(p>0.05)$.

\section{Discussion}

A population of patients undergoing AVR with or without root enlargement in our clinic from 1999 to 2009 was defined. An absolute increase was observed in the number of aortic valve replacement procedures during the studied period. However, the primary pathology leading to surgery, i.e. aortic stenosis, did not change over the years (Table IIIA, B). Parallel to our results, Northrup et al. described a certain increase in aortic valve operations [3]. The profile of aortic valve disease with dominant aortic stenosis depicted in the present study $(n=703 ; 52.5 \%)$ is similar to other surgical series [3-6]. Consistent with the present data, there appears to be a trend towards more surgical complexity in aortic valve operations. However, in contradiction to our results, there are papers advocating more combined $C A B$ in aortic valve operations [3, 7-9]. In this study, we have observed more combined mitral valve operations in comparison to other procedures (312 and 333, respectively; $p>0.05$ ) (Table IVA, B).

The procedure of anterior or posterior annular enlargement may be performed in a patient with a small aortic root to enable the implantation of a larger valve. The posterior approach is the one most commonly used in adults, and it can increase the annular diameter by 2 to $4 \mathrm{~mm}$. In the Nicks technique of root enlargement, the aortotomy is extended downward through the non-coronary cusp and the aortic annulus to the anterior mitral leaflet [1]. In the Manouguian procedure, the aortotomy incision extends downward through the commissure between the left and non-coronary cusps into the interleaflet triangle and the anterior leaflet of the mitral valve [2]. The anterior approach is generally used in the pediatric population. Described by Konno et al. in 1975, this technique, also known as aortoventriculoplasty, is used when annular enlargement of more than $4 \mathrm{~mm}$ is required [10]. Instead of a transverse incision, a longitudinal incision is made in the anterior aorta and extended to the right coronary sinus of Valsalva and then through the anterior wall of the right ventricle to open the right ventricular outflow tract. The ventricular septum is incised, allowing the aortic annulus and left ventricular outflow tract to expand significantly.

Attention needs to be drawn to the fact that the technological development of mechanical valve characteristics has enabled the avoidance of root enlargement and postoperative left ventricular outflow gradient. Over the past

Tab. II. Patients' sex distribution by year

\begin{tabular}{|c|c|c|c|c|c|c|c|c|c|c|c|}
\hline \multirow[t]{3}{*}{ Sex } & \multicolumn{10}{|c|}{ Year } & \multirow[t]{3}{*}{$p$} \\
\hline & 1999 & 2000 & 2001 & 2002 & 2003 & 2004 & 2005 & 2006 & 2007 & 2008 & \\
\hline & $n(\%)$ & $n(\%)$ & $n(\%)$ & $n(\%)$ & $n(\%)$ & $n(\%)$ & $n(\%)$ & $n(\%)$ & $n(\%)$ & $n(\%)$ & \\
\hline Female & 29 (38.7) & $28(34.6)$ & $29(30.5)$ & 39 (35.5) & 48 (37.2) & 49 (29.9) & 48 (31.5) & $54(32.7)$ & 66 (38.2) & $66(34.0)$ & \multirow{2}{*}{0.839} \\
\hline Male & $46(61.3)$ & $53(65.4)$ & $66(69.5)$ & $71(64.5)$ & $81(62.8)$ & $115(70.1)$ & $103(68.2)$ & $111(67.3)$ & $107(61.8)$ & $128(66.0)$ & \\
\hline
\end{tabular}


Tab. IIIA. Aortic valve pathology by year

\begin{tabular}{lccccccccccc} 
& \multicolumn{10}{c}{ Year } & $p$ \\
\cline { 2 - 8 } & 1999 & 2000 & 2001 & 2002 & 2003 & 2004 & 2005 & 2006 & 2007 & 2008 \\
\cline { 2 - 8 } & $n(\%)$ & $n(\%)$ & $n(\%)$ & $n(\%)$ & $n(\%)$ & $n(\%)$ & $n(\%)$ & $n(\%)$ & $n(\%)$ & $n(\%)$ \\
$\begin{array}{l}\text { Aortic } \\
\text { stenosis }\end{array}$ & $39(52.0)$ & $45(55.6)$ & $54(56.8)$ & $60(54.5)$ & $69(53.5)$ & $89(54.3)$ & $81(53.6)$ & $72(43.6)$ & $86(49.7)$ & $108(55.7)$ & 0.527 \\
\hline $\begin{array}{l}\text { Aortic } \\
\begin{array}{l}\text { regurgita- } \\
\text { tion }\end{array}\end{array}$ & $25(33.3)$ & $23(28.4)$ & $30(31.6)$ & $35(31.8)$ & $39(30.2)$ & $50(30.5)$ & $40(26.5)$ & $69(41.8)$ & $64(37.0)$ & $60(30.9)$ & 0.206 \\
\hline $\begin{array}{l}\text { Stenosis + } \\
\text { regurgita- } \\
\text { tion }\end{array}$ & $11(14.7)$ & $13(16.0)$ & $11(11.6)$ & $15(13.6)$ & $21(16.3)$ & $25(15.2)$ & $30(19.9)$ & $24(14.5)$ & $23(13.3)$ & $26(13.4)$ & 0.842 \\
\hline
\end{tabular}

Tab. IIIB. Preoperative aortic valve properties and aortic prosthesis size

\begin{tabular}{lccccccc} 
Properties & \multicolumn{9}{c}{ Aortic valve size } & $p$ \\
\cline { 2 - 7 } & 19 & 21 & 23 & 25 & 27 & $29+31$ \\
\cline { 2 - 7 } & $n(\%)$ & $n(\%)$ & $n(\%)$ & $n(\%)$ & $n(\%)$ & $n(\%)$ & \\
Aortic stenosis & $40(5.3)$ & $199(26.3)$ & $379(50.0)$ & $97(13.2)$ & $20(2.6)$ & $20(2.6)$ & 0.603 \\
\hline Aortic regurgitation & $0(0.0)$ & $234(37.5)$ & $259(41.7)$ & $104(16.7)$ & $26(4.2)$ & $0(0.0)$ & 0.722 \\
\hline Stenosis + regurgitation & $0(0.0)$ & $10(25.0)$ & $31(75.0)$ & $0(0.0)$ & $0(0.0)$ & $0(0.0)$ & 0.855 \\
\hline
\end{tabular}

25 years, changes have been made in the design and configuration of bileaflet prostheses. The sewing ring of the SJM valve has changed (SJM HP) to enable larger valve implantation in any given annulus tissue, as has the ATS Medical prosthesis with its AP design. The sewing ring of the Sulzer CarboMedics valve has been modified so that the valve is implanted in a supravalvular position (top hat model). The On-X valve incorporates advanced pyrolytic carbon technology, using a purer, more flexible coating to allow flanging of the inflow portion of the valve housing, mimicking the normal flow pattern [11]. New mechanical valves have good hemodynamic properties and lower root enlargement rates when compared to the older types.

However, the debate on patient-prosthesis mismatch (PPM) continues. We observed a statistically significant decrease in the number of aortic root enlargement procedures ( $p<0.05$, Table VA). Particularly, the number of Nicks procedures declined over the years ( $p<0.010$, Table VB). Blais et al., Adams et al., and De Paulis et al. reported no difference in overall valve-related mortality between patients who had severe PPM, moderate PPM, or significant PPM [12-14]. On the other hand, Zapolanski et al. and Jamieson et al. reported that PPM was related to early mortality after aortic valve replacement $[15,16]$. Conversely to the decrease in aortic root enlargement operations, this study observed a trend to choose larger aortic valves: size 21 was the one most frequently used in 1999, whereas size 23 was preferred in 2008 ( $p<0.05$, Table VI).

As myocardial protection and prosthetic valve technology improved, hospital mortality declined between the

Tab. IVA. Relationship between additional operation and the used aortic valve size

\begin{tabular}{llccccccc} 
Properties & \multicolumn{9}{c}{ Aortic valve size } & \multicolumn{1}{c}{$p$} \\
\cline { 3 - 8 } & & 19 & 21 & 23 & 25 & 27 & $29+31$ \\
\cline { 3 - 8 } AVR + MVR & $n(\%)$ & $n(\%)$ & $n(\%)$ & $n(\%)$ & $n(\%)$ & $n(\%)$ \\
\cline { 2 - 8 } & AVR + MVR & $22(7.1)$ & $156(50.0)$ & $90(28.6)$ & $22(7.1)$ & $0(0.0)$ & $22(7.1)$ & 0.398 \\
\cline { 2 - 8 } & Other & $0(0.0)$ & $102(30.8)$ & $154(46.2)$ & $77(23.1)$ & $0(0.0)$ & $0(0.0)$ & \\
\hline
\end{tabular}

AVR - aortic valve replacement, MVR - mitral valve replacement

Tab. IVB. Redo cases by year

\begin{tabular}{|c|c|c|c|c|c|c|c|c|c|c|c|}
\hline & \multicolumn{10}{|c|}{ Year } & \multirow[t]{3}{*}{$P$} \\
\hline & 1999 & 2000 & 2001 & 2002 & 2003 & 2004 & 2005 & 2006 & 2007 & 2008 & \\
\hline & $n(\%)$ & $n(\%)$ & $n(\%)$ & $n(\%)$ & $n(\%)$ & $n(\%)$ & $n(\%)$ & $n(\%)$ & $n(\%)$ & $n(\%)$ & \\
\hline Redo & $2(2.7)$ & $2(2.5)$ & $3(3.2)$ & $4(3.6)$ & $3(2.3)$ & $5(3.0)$ & $6(4.0)$ & $4(2.4)$ & $2(1.2)$ & $6(3.1)$ & 0.957 \\
\hline
\end{tabular}


Tab. VA. Aortic root enlargement procedures by year

\begin{tabular}{|c|c|c|c|c|c|c|c|c|c|c|c|c|}
\hline & & \multicolumn{10}{|c|}{ Year } & \multirow[t]{3}{*}{$p$} \\
\hline & & 1999 & 2000 & 2001 & 2002 & 2003 & 2004 & 2005 & 2006 & 2007 & 2008 & \\
\hline & & $n(\%)$ & $n(\%)$ & $n(\%)$ & $n(\%)$ & $n(\%)$ & $n(\%)$ & $n(\%)$ & $n(\%)$ & $n(\%)$ & $n(\%)$ & \\
\hline \multirow{2}{*}{$\begin{array}{l}\text { Aortic root } \\
\text { enlargement }\end{array}$} & with & $5(7.1)$ & $5(6.5)$ & $3(3.2)$ & $4(3.7)$ & $2(1.5)$ & $4(2.5)$ & $2(1.3)$ & $2(1.2)$ & $2(1.1)$ & $2(1.0)$ & 0.000295 \\
\hline & without & 70 & 76 & 92 & 106 & 127 & 160 & 149 & 163 & 171 & 192 & \\
\hline
\end{tabular}

Tab. VB. Nicks and Manouguian procedures by year

\begin{tabular}{|c|c|c|c|c|c|c|c|c|c|c|c|}
\hline & & & & & & & & & & & $p$ \\
\hline & 1999 & 2000 & 2001 & 2002 & 2003 & 2004 & 2005 & 2006 & 2007 & 2008 & \\
\hline & $n(\%)$ & $n(\%)$ & $n(\%)$ & $n(\%)$ & $n(\%)$ & $n(\%)$ & $n(\%)$ & $n(\%)$ & $n(\%)$ & $n(\%)$ & \\
\hline Manouguian & $0(0.0)$ & $1(1.2)$ & $0(0.0)$ & $0(0.0)$ & $0(0.0)$ & $2(1.2)$ & $1(0.7)$ & $1(0.6)$ & $0(0.0)$ & $1(0.5)$ & 0.721 \\
\hline Nicks & $5(6.7)$ & $4(4.9)$ & $3(3.2)$ & $4(3.6)$ & $2(1.6)$ & $2(1.2)$ & $1(0.7)$ & $1(0.6)$ & $2(1.2)$ & $1(0.5)$ & 0.010 \\
\hline
\end{tabular}

Tab. VI. Aortic valve size by year

\begin{tabular}{|c|c|c|c|c|c|c|c|c|c|c|c|}
\hline \multirow{3}{*}{$\begin{array}{l}\text { Aortic valve } \\
\text { size }\end{array}$} & \multicolumn{10}{|c|}{ Year } & \multirow[t]{3}{*}{$p$} \\
\hline & 1999 & 2000 & 2001 & 2002 & 2003 & 2004 & 2005 & 2006 & 2007 & 2008 & \\
\hline & $n(\%)$ & $n(\%)$ & $n(\%)$ & $n(\%)$ & $n(\%)$ & $n(\%)$ & $n(\%)$ & $n(\%)$ & $n(\%)$ & $n(\%)$ & \\
\hline 19 & 8 (10.7) & 9 (11.1) & $10(10.5)$ & $11(10.0)$ & $12(9.3)$ & $12(7.3)$ & $13(8.6)$ & $12(7.3)$ & $9(5.2)$ & $10(5.2)$ & \multirow{6}{*}{0.004} \\
\hline 21 & $32(42.7)$ & $33(40.7)$ & $39(41.1)$ & $47(42.7)$ & 55 (42.6) & $72(43.9)$ & $62(41.1)$ & 55 (33.3) & $67(38.7)$ & 64 (33.0) & \\
\hline 23 & $22(29.3)$ & $26(32.1)$ & $28(29.5)$ & $36(32.7)$ & $42(32.6)$ & $51(31.1)$ & $45(29.8)$ & 59 (35.8) & $70(40.5)$ & 89 (45.9) & \\
\hline 25 & 13 (17.3) & $13(16.0)$ & 18 (18.9) & $16(14.5)$ & $20(15.5)$ & $29(17.7)$ & $31(20.5)$ & 39 (23.6) & 20 (11.6) & $24(12.4)$ & \\
\hline 27 & $0(0.0)$ & $0(0.0)$ & $0(0.0)$ & $0(0.0)$ & $0(0.0)$ & $0(0.0)$ & $0(0.0)$ & $0(0.0)$ & $6(3.5)$ & $6(3.1)$ & \\
\hline 29 & $0(0.0)$ & $0(0.0)$ & $0(0.0)$ & $0(0.0)$ & $0(0.0)$ & $0(0.0)$ & $0(0.0)$ & $0(0.0)$ & $1(0.6)$ & $1(0.5)$ & \\
\hline
\end{tabular}

Tab. VIIA. Mortality by year

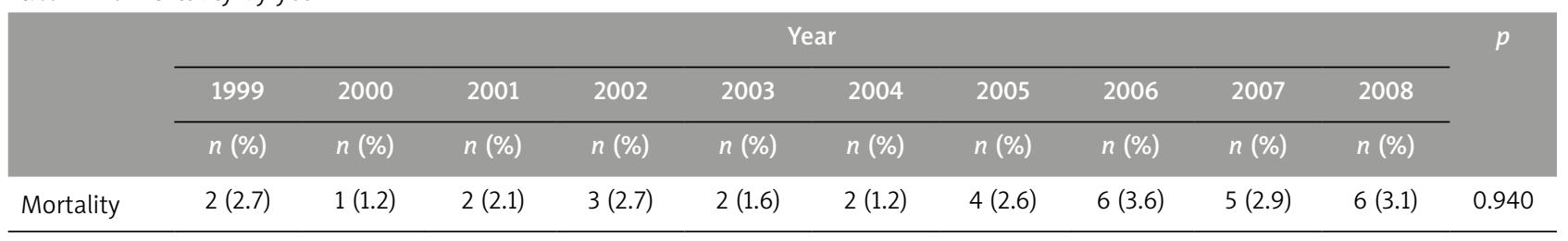

Tab. VIIB. Relationship between hospital mortality and aortic prosthetic valve size

\begin{tabular}{|c|c|c|c|c|c|c|c|}
\hline & \multicolumn{6}{|c|}{ Aortic valve size } & \multirow[t]{3}{*}{$p$} \\
\hline & 19 & 21 & 23 & 25 & 27 & $29+31$ & \\
\hline & $n(\%)$ & $n(\%)$ & $n(\%)$ & $n(\%)$ & $n(\%)$ & $n(\%)$ & \\
\hline Mortality & $7(20.0)$ & $7(20.0)$ & $12(40.0)$ & $7(20.0)$ & $0(0.0)$ & $0(0.0)$ & 0.423 \\
\hline
\end{tabular}

Tab. VIIC. Relationship between additional procedures and mortality

\begin{tabular}{cccc} 
& \multicolumn{2}{c}{ Additional procedure } & $p$ \\
\cline { 2 - 3 } & AVR & AVR-MVR & Other \\
\cline { 2 - 3 } Mortality & $n(\%)$ & $n(\%)$ & $n(\%)$ \\
\hline
\end{tabular}

AVR - aortic valve replacement, MVR - mitral valve replacement 
1980s and 1990s; stable hospital mortality was reported during the 1990s $[6,7,9,17]$. This study has observed stable hospital mortality rates during the studied period (Table VIIA-C, $p>0.05$ ).

Other authors have demonstrated surgical complexity to be a risk factor for hospital mortality [3, 8, 9, 18, 19]. In the present study, we have also observed an increase in early mortality after combined surgery (Table VIIA-C), but without statistical significance $(p>0.05)$. The overall short-term outcomes after AVR with or without combined surgery were excellent. The low risk of AVR associated with combined surgery supports the consideration for earlier surgical referral and intervention in patients with a high likelihood of aortic stenosis progression. It is noteworthy that surgical complexity by itself creates only a modest risk and, therefore, should not be a contraindication to aortic valve surgery in the future.

\section{Conclusions}

This study showed that avoiding the procedure of aortic root enlargement and implanting larger valves with highperformance prostheses is safe.

\section{Disclosure}

Authors report report no conflict of interest.

\section{References}

1. Nicks R, Cartmill T, Bernstein L. Hypoplasia of the aortic root. The problem of aortic valve replacement. Thorax 1970; 25: 339-346.

2. Manouguian S, Seybold-Epting W. Patch enlargement of the aortic valve ring by extending the aortic incision into the anterior mitral leaflet. New operative technique. J Thorac Cardiovasc Surg 1979; 78: 402-412.

3. Northrup WF, Dubois K, Kshettry VR, Teskey JM, Nicoloff DM. Trends in aortic valve surgery in a large multi-surgeon, multi-hospital practice, 19791999. J Heart Valve Dis 2002; 11: 768-779.

4. Dare AJ, Veinot PJ, Edwards WD, Tazelaar HD, Schaff HV. New observations on the etiology of aortic valve disease: a surgical pathologic study of 236 cases from 1990. Hum Pathol 1993; 24: 1330-1338.
5. Roques F, Nashef SA, Michel P. Risk factors for early mortality after valve surgery in Europe in the 1990s: lessons from the EuroScore pilot program. J Heart Valve Dis 2001; 10: 572-577.

6. Brown JM, O'Brien SM, Wu C, Sikora JAH, Griffith BF, Gammie JS. Isolated aortic valve replacement in North America comprising 108,687 patients in 10 years: changes in risk, valve types, and outcomes in the society of thoracic surgeons national database. J Thorac Cardiovasc Surg 2009; 137:82-90

7. Thourani VH, Weintraub WS, Craver JM, Jones EL, Mahoney EM, Guyton RA. Ten years trend in heart valve operations. Ann Thorac Surg 2000; 70: 448-455.

8. Jamieson WRE, Edwards FH, Schwarts M, Bero JW, Clark RE, Grover FL. Risk stratification for cardiac valve replacement. National Cardiac Surgery Database. Ann Thorac Surg 1999; 67: 943-951.

9. Hanayama N, Fazel S, Goldman B, Mitoff P, Sever J, Fremes SE. Contemporary trends in aortic valve surgery: a single center 10 year clinical experience. J Card Surg 2004; 19: 552-558.

10. Konno S, Imai Y, lida Y, Nakajima M, Tatsuno K. A new method for prosthetic valve replacement in congenital aortic stenosis associated with hypoplasia of the aortic valve ring. J Thorac Cardiovasc Surg 1975; 70: 909-917.

11. Cohn L. Cardiac surgery in the adult. Mc Graw Hill Medical, New York 2008.

12. Blais C, Dumesnil JG, Baillot R, Simard S, Doyle D, Pibarot P. Impact of valve prosthesis patient mismatch on short-term mortality after aortic valve replacement. Circulation 2003; 108: 983-988.

13. Adams DH, Chen RH, Kadner A, Aranki SF, Allred EN, Cohn LH. Impact of small prosthetic valve size on operative mortality in elderly patients after aortic valve replacement for aortic stenosis: does gender matter? J Thorac Cardiovasc Surg 1999; 118: 815-822.

14. De Paulis R, Sommariva L, Colagrande L, De Matteis GM, Fratini S, Tomai F, Bassano C, Penta de Peppo A, Chiariello L. Regression of left ventricular hypertrophy after aortic valve replacement for aortic stenosis with different valve substitutes. J Thorac Cardiovasc Surg 1998; 116: 590-598.

15. Zapolanski A, Mak AWC, Ferrari G, Johnson C, Shaw RE, Brizzio ME, Sperling JS, Grau JB. Impact of New York Heart Association classification, advanced age and patient-prosthesis mismatch on outcomes in aortic valve replacement surgery. Interact Cardiovasc Thorac Surg 2012; 15: 371-376.

16. Jamieson EWR, Ye J, Higgins J, Cheung A, Fradet G, Skarsgard P, Germann E, Chan F, Lichtenstein SV. Effect of prosthesis-patient mismatch on long-term survival with aortic valve replacement: assessment to 15 years. Ann Thorac Surg 2010; 89: 51-59.

17. Grunkemeir GL, Li HH, Starr A. Heart valve replacement: a statistical review of 35 years' results. J Heart Valve Dis 1999; 8: 446-471.

18. Hannan EL, Racz MJ, Jones RH, Gold JP, Ryan TJ, Hafner JP, Isom OW. Predictors of mortality for patients undergoing cardiac valve replacements in New York State. Ann Thorac Surg 2000; 70: 1212-1218.

19. Astor BC, Kaczmarek RG, Hefflin B, Daley WR. Mortality after aortic valve replacement: results form a nationally representative database. Ann Thorac Surg 2000; 70: 1939-1945. 